\title{
Analysis on the Cultivation of Students' Professional Ethics Education in Higher Vocational Colleges from the Perspective of Ideological and Political Education
}

\author{
Hong-da ZHANG \\ China University of Mining and Technology (Beijing), China
}

Keywords: Higher vocational colleges Ideological and political education professional ethics education.

\begin{abstract}
General secretary Xi Jinping emphasized at the national conference on ideological and political work in colleges and universities that we should insist on making moral education the central link, which is the regulation of the direction and inner soul of higher education. Ideological and political education is the fundamental guarantee to realize quality education, which is the important content of quality education in colleges and universities, and the most important task is to strengthen professional ethics education. As an important task of ideological and political education in colleges and universities, professional ethics education is conducive to promote the all-round development of students and social progress. This paper discusses the correlation between ideological and political education and professional ethics education, as well as the cultivation measures to improve the professional ethics quality of students in higher vocational colleges.
\end{abstract}

\section{Introduction}

Ideological and political education is an important part of college students' education, which plays an irreplaceable role in the cultivation of talents in higher vocational colleges. As one of the contents of ideological and political education, professional ethics education is of great significance to help students form good moral habits and improve the level of professional ethics. General secretary Xi Jinping stressed at the national conference on ideological and political work in colleges and universities that adhere to khalid ents as the key link, the ideological and political work should be carried out throughout the entire process of education and teaching to achieve full education, all-round education, and strive to create a new situation in the development of higher education in China. This is the direction of higher education and the provisions of the inner soul. The integration of ideological and political education and professional ethics education in higher vocational colleges and the cultivation of moral talents as the central link not only enhance the effectiveness of ideological and political education, but also improve the overall level of students' professional ethics and promote the comprehensive and sustainable development of students.

\section{The Relationship between Professional Ethics Education and Ideological and Political} Education

Professional Ethics Education and Ideological and Political Education Complement Each Other. Ideological and political education in higher vocational colleges is to carry out world outlook education, political outlook education, outlook on life education, rule of law education and moral outlook education, and strive to cultivate college students' moral, intellectual, physical and aesthetic development in an all-round way. Professional ethics is the sum of all psychological consciousness, code of conduct and code of conduct that meet the professional requirements in the process of professional activities. Professional ethics education and ideological and political education complement each other, interact and cooperate with each other, and jointly guide students to form a correct and scientific world outlook, outlook on life and values.

Professional Ethics Education is an Important Channel for Improving Ideological and Political Education. The foundation of colleges lies in high moral values establishment and people cultivation. There are many ways of ideological and political education. Because of the natural 
particularity of higher vocational colleges, it is inevitably required that professional ethics education and ideological and political education should be closely integrated, and ideological and political education be infiltrated in the process of cultivating professional quality, so as to further improve the ideology and political education effectiveness. Therefore, to strengthen vocational ethics education in vocational colleges has become an indispensable and important channel for improving of ideological and political education effectiveness.

Strengthening Ideological and Political Education is the Basic Guarantee for Improving Professional Moral Education. The ideological and political work in colleges is related to the fundamental issues about what kind of people are cultivated in colleges and universities, how to cultivate people and for whom. For higher vocational education, strengthening professional ethics education is not only a historical law for the growth of talents, but also a realistic requirement for enhancing graduates' employment competitiveness. The basic guarantee for ensuring the overall development of students in higher vocational schools is to conduct ideological and political education.

\section{The Significance of Improving Vocational College Students' Professional Moral Education and Enhancing Ideological and Political Education}

It is Beneficial to Cultivate Qualified Technical and Skilled Talents. In today's era of knowledge economy, high-quality compound-type talents have at least the following capabilities: moral quality, innovation quality, aesthetic quality, skill quality, and physical fitness. Professional ethics education helps students establish an awareness of hard work and dedication, guiding them to work hard and to strive for improving business standards and excellence, and giving full play to their creativity in the workplace. Ideological and political education is aimed at cultivating students' good will quality, guiding them to learn about the correct view of life and values, and guiding them to establish ambitious ideas and improve their overall quality. Therefore, educating higher vocational students with scientific and reasonable professional ethics education and ideological and political education to can not only cultivate excellent professional and technical skills for our country, but standing at the height of the country's prosperity and development, can also provide the prosperity of the motherland with human resources.

It is Beneficial to Achieve the Goal of Moral Education. Moral education is an important part of education. Professional ethics education has always been an important content of moral education. It can be known from the related documents that the reality in our country is to incorporate professional ethics education into the category of ideological and political education for higher vocational students. This indicates that professional ethics education and ideological and political education are two closely linked concepts and cannot be separated in practical work. Taking high moral values establishment and people cultivation as the centerpiece of the current ideological and political work of higher education, educators must focus on students, care for students, and serve for students, and they constantly improve students' ideological level, political awareness, moral quality and cultural quality, to make them become both talented and fully developed talents. Combining ideological and political education and professional ethics education can integrate the teaching resources and promote the abundance and effective use of it, which can realize the moral education goal.

It is Beneficial to Promote the All-round Development of Students in Higher Vocational Colleges. General Secretary $\mathrm{Xi}$ Jinping pointed out that ideological and political work is fundamentally a man-made job. It must focus on students, take care of students, and serve students, and constantly improve students' ideological level, political awareness, moral quality, and cultural quality, make students become the talents of all-round development, have both ability and political integrity. In today's society, the demand for talent is not limited in a skill, but requires the skill of high-quality talents. All-round development is the core and essence of Marxism on human development, and it is also an important criterion for educational training goals in China's education policy. To improve the professional ethics education of higher vocational college students and enhance ideological and political education are conducive to promoting the all-round development 
of students in higher vocational colleges. Higher vocational colleges should not only pay attention to the professional learning and skills improvement of students, but also pay attention to the cultivation of students' ideological qualities, allow them to have professional qualities, and become technical and technical talents that meet the needs of society.

\section{The Ideological and Political Education in Vocational College Students Vocational Ethics Education Training Measures}

Adhering to the Guiding Role of Socialist Core Values. Socialist core values are the guiding ideology of all ideological and political education and professional ethics training. Ideological and political education in higher vocational colleges must carry out the socialist core values. Social values are the evaluation criteria, viewpoints, attitudes, and behaviors of people on good and bad, good and evil, gains and losses, and ugliness. Values belong to the category of social ideology and determine people's ideological orientation and behavior choices. The core values are the main body and soul of a social ideology, which have a strong leading and integration role in social consciousness and social ideological trend. On February 12, 2014, "People's Daily" published socialist core values and published an editorial entitled "The people have the power to believe in the country," and compared the core values to "the spiritual calcium of the Chinese nation." The core values of socialism are 24 words. From a national perspective, they are wealthy, strong, democratic, civilized, and harmonious. From a social perspective, they are free, equal, fair, and the rule of law. From the perspective of citizens, they are patriotic, dedicated, honest, and friendly. The three levels of the country, society, and citizens are involved. The core values carry positive energy. The core values of socialism are not only the core values of socialism in our country, but also meet the current professional needs. They are the core content of professional ethics education and are important prerequisites for realizing the ideological and political education of students in higher vocational colleges. Adhere to the guiding role of socialist core values, let students clearly establish the ideological and moral goals of personal development in ideological and political education and professional moral education, in order to promote the combination of ideological and political education and professional ethics education, in order to enhance the effectiveness of ideological and political education.

Cultivating Students to Develop Good Professional Ethics Habits. Cultivating students to develop good professional ethics habits plays a vital role in the future growth of students, we pay attention to the cultivation of professional ethics in ideological and political education.

First, to highlight the cultivation of the spirit of love and dedication. The love and dedication is the primary norm advocated by socialist professional ethics and the primary link of professional ethics education. The cultivation of the spirit of love and dedication is the basic element of improving the future professional moral state of college students.

Second, make clear the cultivation of the principles of justice. Justice is a professional ethics known for thousands of years. It requires workers to use their national laws, regulations, rules, and public moral preparations as their standards and deal with issues fairly. Clearly cultivating the principles of doing justice for the people can allow students to bravely pursue the truth and behave arrogantly.

Third, to strengthen the cultivation of social thought, the dedication of society is the highest pursuit of socialist professional ethics and the best embodiment of serving the people and the spirit of collectivism. While strengthening the cultivation of students' knowledge and skills, it is even more necessary to strengthen the cultivation of the sense of responsibility and dedication of higher vocational students. Therefore, it is necessary to establish the objective of both ideological and political education and professional moral education, stick to the correct guidance of socialist core values, so that the education level of higher vocational colleges can be improved rapidly.

Increasing the Penetration of Ideological and Political Education in Professional Knowledge Education. Ideological and political education is a multifaceted rather than isolated existence. It is very important for improving the effectiveness of Ideological and political education to combine ideological and political education with professional knowledge education and adopting various 
forms of extensive infiltration. The cultivation of professional ethics cannot be separated from the cultivation of professional knowledge and ability, they should not only have good professional ethics, but also have excellent professional skills as a contemporary vocational college student. In the fierce competition of today's society, the employer's demand for technical and skilled talent is one of the indicators for admission at the time of recruitment. Therefore, it is particularly important for students to have solid professional skills. The cultivation of students' professional skills in higher vocational colleges should focus on professional knowledge, professional skills, and the ability of organization and management. Educators in higher vocational colleges must seriously study and solve how to make the students of higher vocational colleges successfully complete the transition from school to work after graduating. So that they can better adapt to the society and enter jobs immediately after entering jobs.

Strengthen the Coordination of Professional Ethics Education and Ideological and Political Education. Higher vocational college students' ideological and political education and professional moral education are complementary and interact with each other. This determines that these two aspects of the work cannot be separated, but must progress together and run coordinate.

First, carry out honesty education to improve students' integrity moral quality. Integrity is the moral concept that has always been respected in Chinese outstanding traditional culture. It is also a basic moral quality that students in higher vocational colleges should possess. Higher vocational colleges should comprehensively strengthen the integrity education for students in school, seriously explore practical ways and methods, and infiltrate integrity of this morality into all aspects of student learning and life.

Second, strengthen teamwork education to improve students' competitiveness. Teamwork is the most basic requirement of modern enterprises. Nowadays, most students in higher vocational colleges are now only children, and most of them are independent of the experience and consciousness of cooperating with others. If students lack teamwork spirit before they enter the career, they will lose excellent competition opportunities. If students have strong teamwork ability, they will undoubtedly become an advantage in the competition. Therefore, as a higher vocational college, it is necessary to strengthen the education and cultivation of students' teamwork spirit. Through the mastery of knowledge and practical training, higher vocational college can improve students' teamwork consciousness and level.

Third, strengthen psychological counseling to improve the professional psychological quality of higher vocational college students. The purpose of cultivating professional psychological quality of higher vocational college students is to help them solve better the career choices and adaptation problems encountered in employment. At the same time, cultivate their ability to adjust emotions, adapt to the environment, and communicate with others. Higher vocational colleges could set up mental health related courses, establish student psychological files, and provide information for ideological and political education. Help students learn to analyze their advantages and disadvantages objectively, and face success and failure correctly.

\section{Reference}

[1] Xi Jinping emphasized at the national conference on ideological and political work in colleges and universities -- Permeate the entire process of education and teaching through ideological and political work to create a new situation for the development of higher education in China [N]. People's Daily, 2016-12-09(1).

[2] Higher Vocational Education Innovation Development and Action Plan (2015-2018) [Z]. Ministry of Education, 2015.

[3] W.B.Chen Y.C.Zhang. Principles of ideological and political education [M]. Higher Education Press (Beijing), 2009.

[4] B.Li. Vocational Moral Education Theory and Exploration of Higher Vocational College Students. [M]. Hunan Normal University Press (Hunan), 2011. 